\title{
Mineralogy, Geochemistry and Provenance of Coastal Sands from Greece: New Insights on the REE Content of Black Coastal Sands from Aggelochori Area, N.-Greece
}

\author{
Argyrios Papadopoulos ${ }^{1, *(\mathbb{D})}$, Stylianos Lazaridis ${ }^{2}{ }^{(D}$, Afroditi Kipourou-Panagiotou ${ }^{2}$, Nikolaos Kantiranis ${ }^{2}{ }^{(\mathbb{D}}$, \\ Antonios Koroneos ${ }^{2}$ and Konstantinos Almpanakis ${ }^{3}$ \\ 1 School of Chemistry-Laboratory of Chemical \& Environmental Technology, \\ Aristotle University of Thessaloniki, 54124 Thessaloniki, Greece \\ 2 Departments of Mineralogy-Petrology-Economic Geology School of Geology, Faculty of Sciences, \\ Aristotle University of Thessaloniki, 54124 Thessaloniki, Greece; slazarid@geo.auth.gr (S.L.); \\ akipourou@bio.auth.gr (A.K.-P.); kantira@geo.auth.gr (N.K.); koroneos@geo.auth.gr (A.K.) \\ 3 Department of Physical and Environmental Geography, School of Geology, \\ Aristotle University of Thessaloniki, 54124 Thessaloniki, Greece; albanaki@geo.auth.gr \\ * Correspondence: argpapad@geo.auth.gr
}

check for updates

Citation: Papadopoulos, A.; Lazaridis, S.; Kipourou-Panagiotou,

A.; Kantiranis, N.; Koroneos, A.; Almpanakis, K. Mineralogy,

Geochemistry and Provenance of Coastal Sands from Greece: New Insights on the REE Content of Black Coastal Sands from Aggelochori Area, N.-Greece. Minerals 2021, 11, 693. https://doi.org/10.3390/min11070693

Academic Editor: Harald G. Dill

Received: 18 May 2021

Accepted: 24 June 2021

Published: 28 June 2021

Publisher's Note: MDPI stays neutral with regard to jurisdictional claims in published maps and institutional affiliations.

Copyright: (c) 2021 by the authors. Licensee MDPI, Basel, Switzerland. This article is an open access article distributed under the terms and conditions of the Creative Commons Attribution (CC BY) license (https:// creativecommons.org/licenses/by/ $4.0 /)$.

\begin{abstract}
Beach sands from Aggelochori coast line are investigated for their geochemistry and REE content, mineralogy and their provenance. These fluvial sands bear heavy minerals enriched horizons (containing minerals such as magnetite, zircon, ilmenite, hematite, rutile and titanite) that can be distinguished due to their black color and are formed usually due to the action of sea waves that deposit the heavy minerals and remove the lighter ones. After a suitable processing (washing, sieving, drying and magnetic separation) of the samples, the mineral constituents and their presence (wt.\%) were estimated by XRD. Among the samples, the one being simultaneously the more fine grained and the more zircon-enriched (as suggested by XRPD data and optical microscopy analysis) has been selected for further geochemical analyses. The major and trace elements contents were compared to previously studied REE enriched beach sands from Kavala and Sithonia. Beach sands from Aggelochori area appear to have relatively low REE contents. Considering the provenance of these sediments, we suggest that these sands, are a product of the erosion of multi-sources, including the near-by Monopigado granite, as well as metamorphic rocks, as indicated by the presence of rutile and both ilmenite and magnetite in some samples. Therefore, there are indications of a complex flow pattern that existed at the paleo-catchment area of the deposition.
\end{abstract}

Keywords: black sands; REE; sediments provenance; geochemistry; mineralogy

\section{Introduction}

Coastal sands can be enriched in heavy minerals. The latter, can be enriched in elements that are relatively rare in earth's crust. There is a particular focus from the scientific community as far as REE's deposits. In the case of beach placer deposits, there are numerous studies referring to areas of economic value due to their REE and other critical elements content [1]. Particularly in Greece there are several publications studying the REE and natural radioactivity content in beach placer deposits [1]. Coastal sands from Aggelochori area close to Thessaloniki (N.-Greece) have been studied by Filippidis et al. 1997 [2] but there are no studies of source formation of the beach placers, up to now.

This study aims to provide additional mineralogical and geochemical data about this area. The data on the REE budget and other trace elements of economic value are given and have been compared to other beach sands enriched in REE in Greece. Therefore, implications of the economic potential of these sands can be made. Additionally, some preliminary data upon the provenance of the beach sands studied is provided. 


\section{Geological Setting}

Rocks of the Chortiatis Magmatic Suite and eastern Vardar Ophiolites (Guevgueli, Thessaloniki-Metamorphosis and Kassandra-Sithonia exposures) predominate the general geological frame of the surrounding area (Figure 1). They form a complex middle to late Jurassic arc/back-arc spreading system [3]. Chortiatis Magmatic Suite is made of intensely deformed acidic and intermediate igneous rocks [4-6]. Eastern Vardar Ophiolites suite is made of non-metamorphosed ultramafics/mafics/intermediate igneous rocks [7] with intercalations of Jurassic-earliest Cretaceous reef limestones [8,9].

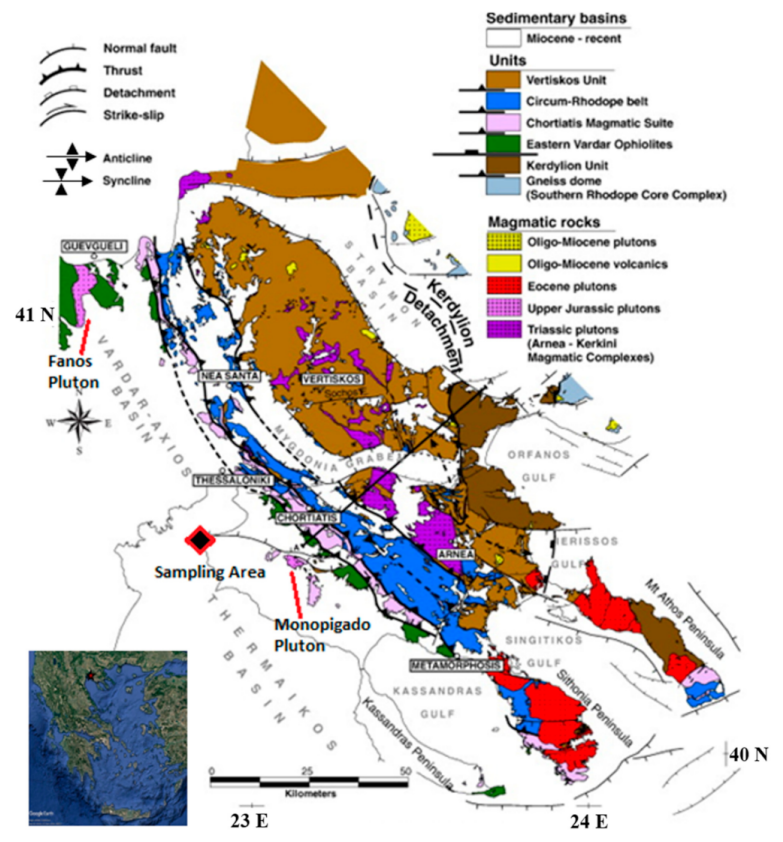

Figure 1. Geological sketch of the wider area ([3] after modifications).

Aggelochori area is placed on Vardar-Axios basin composed by Miocene and recent sediments. Fanos [10] and Monopigado [11] plutons belong to the Upper Jurassic plutons intruding the Vardar-Axios ophiolites.

The sampling site is a steep coastal cliff with a length of $200 \mathrm{~m}$, with a narrow beach at the base, where black sands are interbedded in the upper shore-face strata. The coastal black sands were initially studied by Filippidis et al. 1997 [2].

The cliffs consist of nearly horizontal layers of an Upper-Pliocene fluvio lacustrine sequence consisting of sands and pebbles in paleo-river channels and floodplains with loam and calcareous marly sedimentation. This sequence is overtopped by a reddish fluvial Pleistocene formation, on an erosional sequence boundary [12]. The fossil record is strong involving terrestrial tortoise, micromammals and primates $[13,14]$ that verified the sediment age of Upper-Pliocene with reasonable accuracy.

\section{Material and Methods}

\subsection{Sample Preparation}

Four samples (AGG-1-4 with a total weight of $5 \mathrm{~kg}$ ) were collected from the coastal cliff, at a height of $5 \mathrm{~m}$ above sea level at roughly $50 \mathrm{~m}$ distance to each other, across the same stratigraphic layer. The samples were collected from the Upper-Pliocene fluvio lacustrine paleo riverbeds (Figure 2). 




Figure 2. The sampled cliff and the black sand layer.

Afterwards, the samples were washed with clean water to remove any shells and algae and dried at the oven at $50{ }^{\circ} \mathrm{C}$ for $48 \mathrm{~h}$. The samples were dried and sieved to get their grain size fractions (gravel, sand, silt + clay).The samples have been also studied under optical microscopy in order to roughly assess their mineralogical composition. The grain-size fraction of 1-0.063 $\mathrm{mm}$ has been used for magnetic separation in order to assess any differences between the non-magnetic and magnetic fractions.

For the mineral separations, a Frantz isodynamic separator was used to determine the w.t. \% magnetic and non-magnetic fractions of the whole sample (Table 3), after the removal of magnetite with hand magnet. The magnetic fraction was obtained after passing at $<1.7 \mathrm{amp}$ at forward and side slope of $15^{\circ}$ and $25^{\circ}$, respectively, while the non-magnetic fraction passed at $>1.7 \mathrm{amp}$ at same settings.

\subsection{X-ray Diffractometry}

The mineralogical composition of randomly oriented powder samples was determined by X-ray powder diffraction (XRPD) using a Philips PW1710 diffractometer (Department of Mineralogy, Petrology, Economic Geology, School of Geology, Aristotle University of Thessaloniki, Thessaloniki, Greece) with Ni-filtered $\mathrm{Cu}-\mathrm{K}_{\mathrm{a}}$ radiation. The counting conditions of the XRPD study were: step size $0.01^{\circ} 2 \theta, 2 \theta$ range $3-65^{\circ}$ and scan speed: $1.2^{\circ} / \mathrm{min}$. Quantitative estimates of the abundance of the mineral phases were derived from the XRPD data using the intensity of certain reflections, the density and the mass absorption coefficient for $\mathrm{Cu}-\mathrm{K}_{\mathrm{a}}$ radiation of the minerals present [15].

\subsection{Major and Trace Elements Analysis}

The REE and other trace elements content of the whole-rock samples was determined by ICP-MS at Activation Laboratories (ACTLABS, Ancaster, ON, Canada) following a lithium borate fusion and dilute acid digestion. The element analyses were performed with a XRF JEOL JSX-60PX at the Department of Mineralogy-Petrology-Economic Geology, School of Geology, Aristotle University of Thessaloniki, after a lithium borate fusion. 


\section{Results and Discussion}

\subsection{Textural Characteristics}

In Table 1 the lithological characteristics of the studied sediment sample are given, while in Figure 2, the lithological classification of the studied samples according to Folk et al. 1970 [16] is presented.

Table 1. Grain size (wt.\%) and classification of the studied samples.

\begin{tabular}{|c|c|c|c|c|c|}
\hline \multirow{2}{*}{ Sample } & \multirow{2}{*}{ Gravel (>2 mm) } & \multirow{2}{*}{$\begin{array}{c}\text { Sand } \\
(2-0.63 \mathrm{~mm})\end{array}$} & \multirow{2}{*}{$\begin{array}{c}\text { Silt+Clay } \\
(<0.063 \mathrm{~mm})\end{array}$} & \multicolumn{2}{|c|}{ Lithological Class } \\
\hline & & & & Folk et al. (1970) & Schlee (1973) \\
\hline AGG-1 & 86.38 & 10.57 & 3.05 & Gravel & Gravel \\
\hline AGG-2 & 67.73 & 30.13 & 2.14 & Sandy gravel & Gravel \\
\hline AGG-3 & 33.88 & 64.27 & 1.85 & Sandy gravel & Gravelly sediments \\
\hline AGG-4 & 55.98 & 42.29 & 1.73 & Sandy gravel & Gravel \\
\hline
\end{tabular}

There is a good agreement between the two classifications as the studied samples classified as gravel (sample AGG-1) and sandy gravel (samples AGG-2-4) according to Folk et al. 1970 [16] and gravel (samples AGG-1, 2 and 4) and gravelly sediment (sample AGG-3) according to Schlee 1973 [17].

The depositional setting of the samples has cross-stratification, with NW-SE paleo current direction. The paleo-riverbed granules found mainly on the basis of the crossstratified sandy beds showing an imbrication, indicating a NW-SE flow direction, which is in good agreement with Syrides 1990 [12].

Based on these classifications it can be stated that the examined samples are typical samples of fluvial transportation and deposition, i.e., conditions of relatively high dynamic transport energy for a relatively short distance $[18,19]$ or excessive flow of subtropical conditions over an extensive catchment area [20].

The wt.\% magnetic and non-magnetic fractions determined for the $1-0.063 \mathrm{~mm}$ grainsize fraction of the samples is given in Table 2. According to Papadopoulos et al. 2014 [21], The magnetic fraction might contain minerals such as epidote, allanite, garnet, muscovite, biotite and hornblende, while the heavy non-magnetic fraction might contain zircon, monazite, apatite and titanite.

Table 2. Magnetite w.t.\% and magnetic and non-magnetic fractions of the whole samples.

\begin{tabular}{ccc}
\hline Sample & Magnetic Fraction \% & Non-Magnetic Fraction \% \\
\hline AGG-1 & 70.61 & 29.39 \\
AGG-2 & 81.48 & 18.52 \\
AGG-3 & 72.28 & 27.72 \\
AGG-4 & 80.14 & 19.86 \\
\hline
\end{tabular}

\subsection{Mineralogical Composition}

In Table 3 the mineralogical composition (wt.\%) of the studied samples is given. According to Table 2 , the examined samples consist mainly of quartz (22-40 wt.\%), feldspars (plagioclase and K-rich feldspars, 18-30 wt.\%) and phyllosilicate minerals (micas and chlorite, 13-44 wt.\%).The following concentrations were identified for pyroxene (1-4 wt.\%), amphibole (1-3 wt.\%), dolomite (2-3 wt.\%) and heavy minerals such as magnetite (5-9 wt.\%), zircon (2-3 wt.\%), hematite ( $2 \mathrm{wt.} \%)$, ilmenite ( $2 \mathrm{wt} . \%)$, rutile (4 wt. $\%$ ) and titanite (2-5 wt. $\%$ ). Of course, in case of accessory minerals, XRPD is not suitable for quantitative calculations, so the respective values must be carefully considered. 
Table 3. Mineralogical composition (wt.\%) of the studied whole samples.

\begin{tabular}{|c|c|c|c|c|c|c|c|c|c|c|c|c|c|c|}
\hline Mineral & $\mathrm{Qz}$ & P1 & $\mathrm{Kf}$ & Px & Am & Do & $\mathbf{M}$ & $\mathrm{Ch}$ & Mt & $\mathbf{H t}$ & $\mathrm{Ilm}$ & $\mathbf{R u}$ & $\mathbf{T i}$ & $\mathrm{Zr}$ \\
\hline AGG-1 & 22 & 14 & 4 & - & - & - & 16 & 28 & 9 & - & - & 4 & - & 3 \\
\hline AGG-2 & 38 & 26 & 4 & 4 & 1 & 3 & 9 & 4 & 5 & 2 & 2 & - & - & 2 \\
\hline AGG-3 & 40 & 30 & - & 1 & 1 & 2 & 9 & 7 & 5 & - & - & - & 2 & 3 \\
\hline AGG-4 & 31 & 21 & 7 & 2 & 3 & 3 & 13 & 7 & 5 & - & - & - & 5 & 3 \\
\hline
\end{tabular}

Qz: Quartz, Pl: Plagioclase, Kf: K-feldspar, Px: Pyroxene, Am: Amphibole, Do: Dolomite, M: Mica, Ch: Chlorite, Mt: Magnetite, Ht: Hematite, Ilm: Ilmenite, Ru: Rutile, Ti: Titanite, Zr: Zircon.

According to Blatt et al. 1972 [22] heavy minerals are very useful constituents for sediments provenance studies. The presence of heavy minerals in the clastic sediments is mainly due to the extensive alteration, due to erosion and transportation, of the weathering products of the parent rocks. They are usually present in quantities $<1 \%$. According to Tucker, 2001 [23]. Zircon, tourmaline, rutile and garnets are the most abundant non opaque heavy minerals, while pyrite, magnetite, ilmenite and chromite the most abundant opaque heavy minerals. Also, the presence of apatite, biotite, hornblende, magnetite, and zircon in the assemblage of heavy minerals is a strong indication of igneous rocks weathering processes [24]. Zircon which is readily insoluble to weathering processes can be of multi-source, rutile indicates the origin from metamorphic rocks and the presence of Fe-Mg minerals indicates the mineralogical immaturity of the samples ([24] and references therein). This observation is strengthened in the studied samples by the significant presence of quartz and feldspars, as well as the presence of chlorite that may be derived from the alteration of initial biotite.

Finally, the presence of iron-magnesium rich minerals (pyroxene, amphibole, chlorite) as well as high amounts of feldspars (mainly plagioclase) shows that the studied sediments are mineralogically immature. The presence of these minerals, which lead to mineralogical immaturity, is a clear indication of limited processing of the detrital material in the deposition basin which in turn is the result of the large supply of the river system of the study area in short periods of time and rapid transport and sediment deposition. The climate of the Upper-Pliocene was subtropical with wet and dry periods [20], which does not favor the most primary mineral alteration processes. Tsirambides and Kantiranis 1998 [25] studying the composition and origin of the modern river deposits of Evros agree with this estimation and found that the rapid sedimentation during periods of heavy rainfall limits the physical and chemical processes, as well as the degree of sediments re-processing leading to immature sediments both texturally and mineralogically.

\subsection{Chemical Study}

In Table 4 the chemical composition (wt.\%) of major oxides and trace elements (ppm) of sample AGG-3,is given along with the composition of different fractions. Sample AGG-3 was chosen for geochemical analyses, because it presumably has the highest REE budget among the samples, as it is the most fine-grained and has the highest amount of zircons as suggested by XRPD and optical microscopy. According to Table $3, \mathrm{SiO}_{2}$ is the major oxide contained in the studied samples, followed by $\mathrm{Al}_{2} \mathrm{O}_{3}, \mathrm{Fe}_{2} \mathrm{O}_{3 \mathrm{t}}, \mathrm{K}_{2} \mathrm{O}$ and $\mathrm{Na}_{2} \mathrm{O}$. The magnetic fraction is enriched in $\mathrm{Fe}_{2} \mathrm{O}_{3}, \mathrm{MgO}, \mathrm{CaO}$ and $\mathrm{TiO}_{2}$, while the non-magnetic fraction in $\mathrm{SiO}_{2} \cdot \mathrm{MnO}$ concentrations are also high in the magnetic fraction, in comparison with the $\mathrm{MnO}$ concentrations of the common rocks, implying the possible presence of $\mathrm{MnO}$ coatings on mineral constituents. 
Table 4. Major and trace element composition of several fractions of the sample AGG-3.




The distribution of REE's in the separated fractions of the studied samples is presented in Figure 3. It is a typical LREE enriched pattern which is widely reported in the upper continental crust. The non-magnetic $1-0.063 \mathrm{~mm}$ fraction appears to be the most REE enriched.

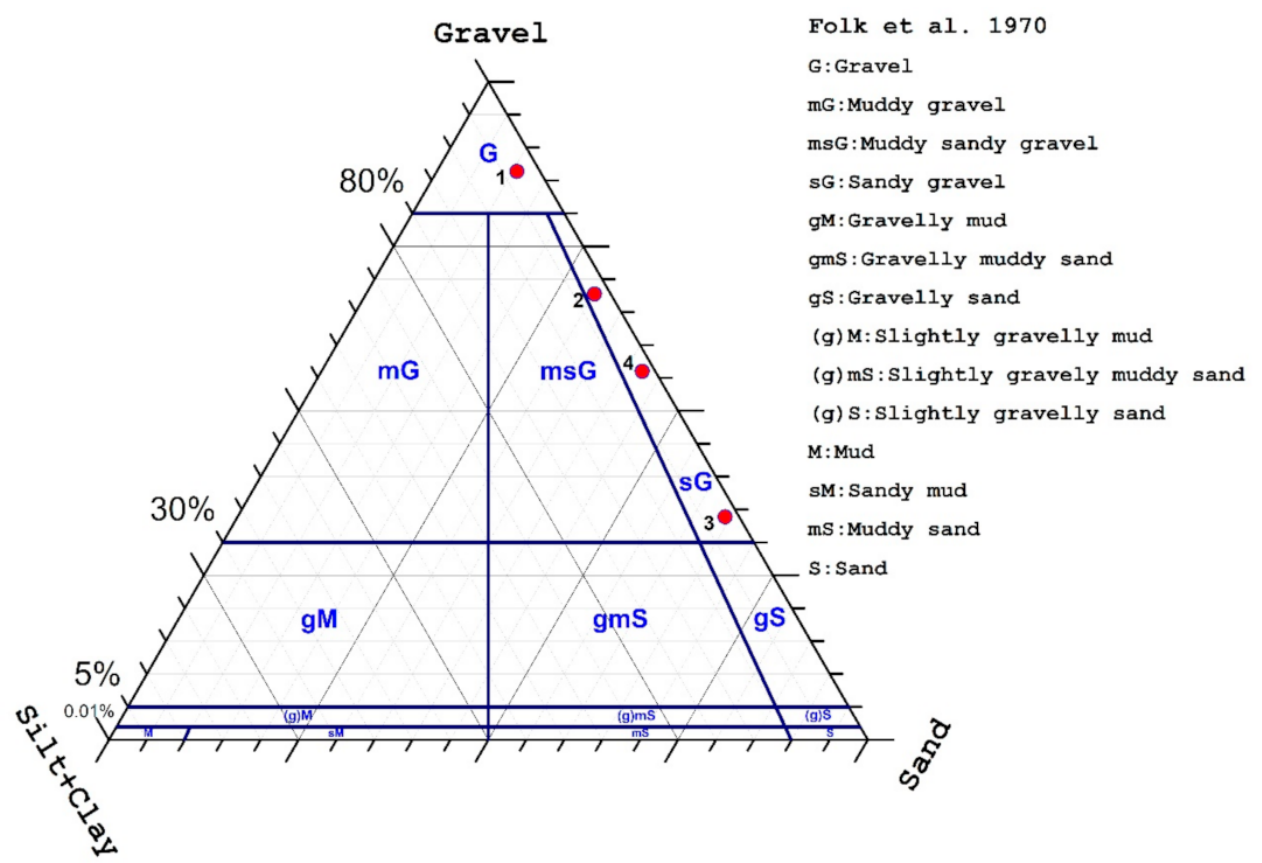

Figure 3. Lithological classification of the studied samples.

As indicated in Figure 4, presenting the REE distribution of the separated fractions (according to grain size and magnetic susceptibility), the non-magnetic fraction, has the highest REE values compared to the upper crust. These, especially for the LREE's (La, Ce, $\mathrm{Pr}, \mathrm{Nd}, \mathrm{Sm}, \mathrm{Eu}$ ), are increased two times than the Upper Continental Crust (UCC). The latter is also supported by Figure 4, indicating that regardless the grain size, LREE values are by one order of magnitude greater than the HREE's in the studied samples.

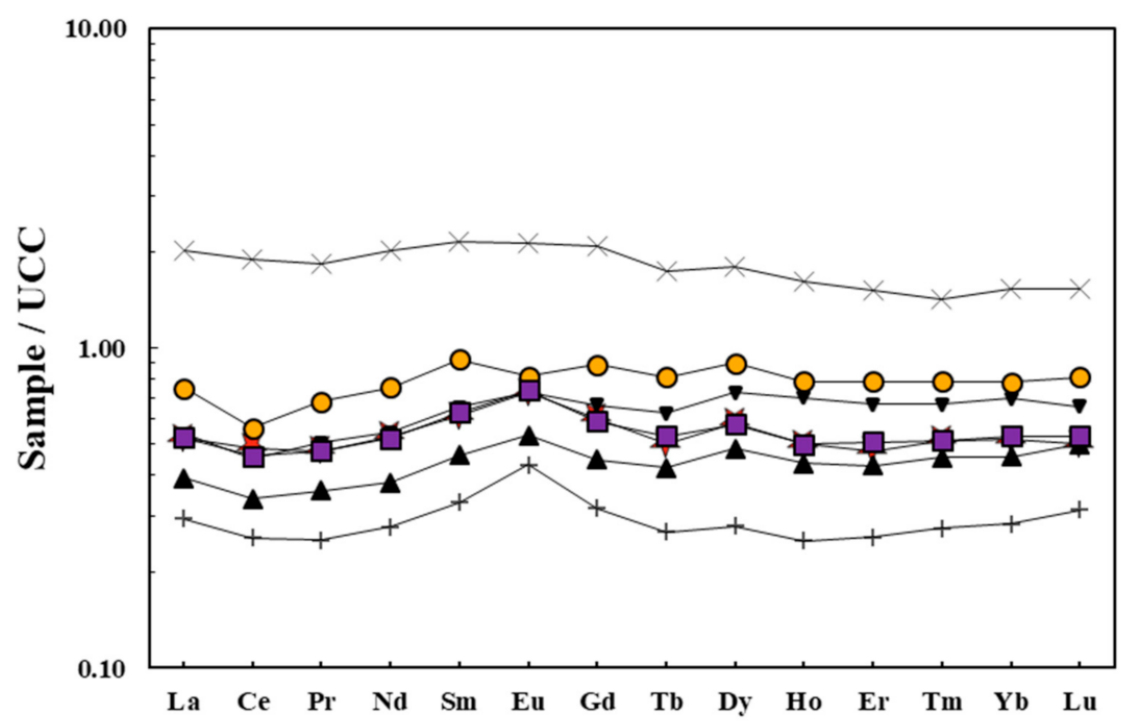

Figure 4. REE distribution of the separated fractions according to grain size and magnetic susceptibility (UCC normalization after [26]). Symbols as in Figure 5. 


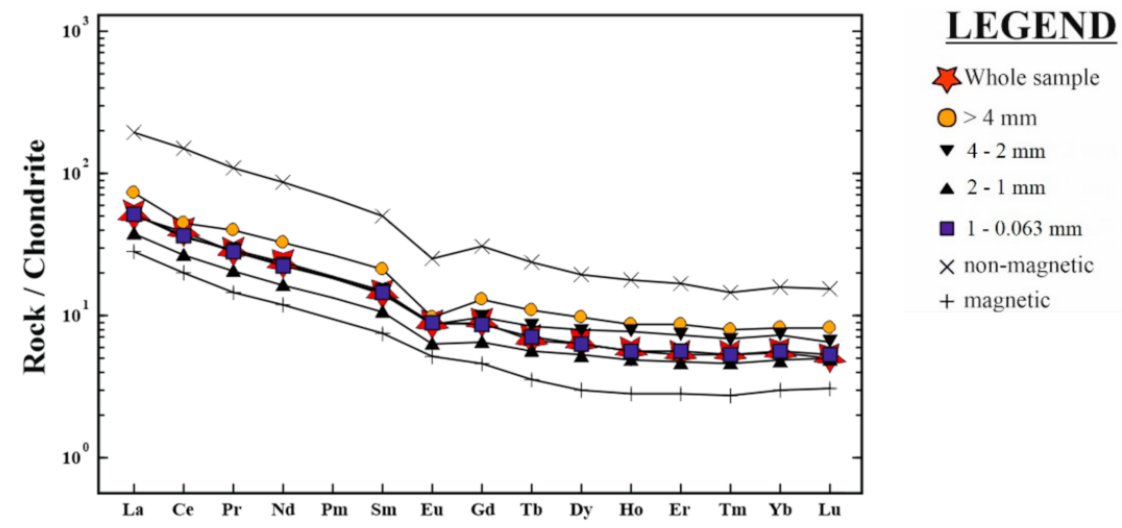

Figure 5. REE patterns of the separated fractions (Normalization after [27]).

In the case of other elements, namely $\mathrm{Zr}, \mathrm{Hf}, \mathrm{Ta}, \mathrm{Nb}$, Th and $\mathrm{U}$, as well as $\mathrm{Cs}, \mathrm{Rb}, \mathrm{Ba}$ and $\mathrm{Sr}$, it seems that grain size does not significantly affect their content (Figures 6 and 7).

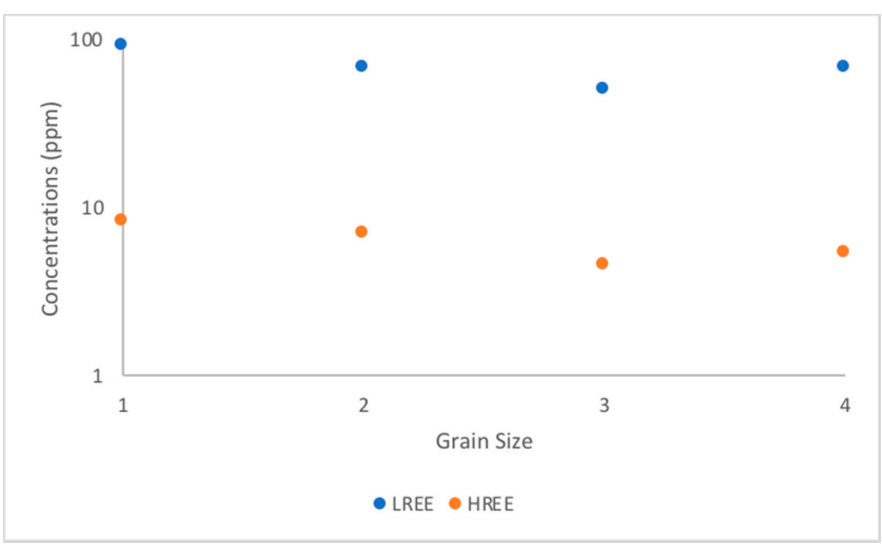

Figure 6. Grain size versus REE content of the fractions. 1: $>4 \mathrm{~mm}, 2: 4-2 \mathrm{~mm}, 3: 2-1 \mathrm{~mm}$, and 4: $1-0.063 \mathrm{~mm}$.

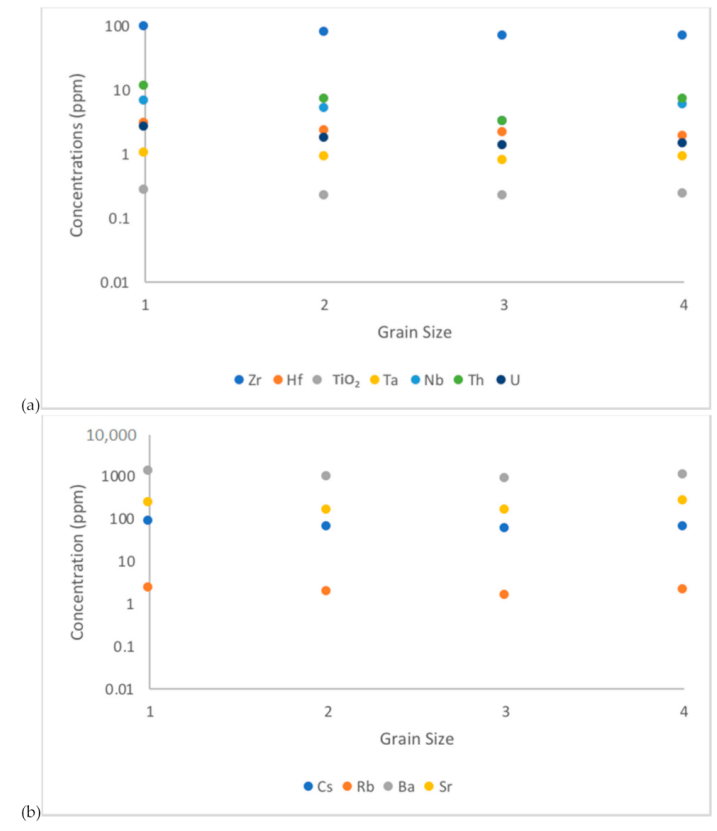

Figure 7. Grain size vs concentrations of $\mathrm{Zr}, \mathrm{Hf}, \mathrm{TiO}_{2}(\%)(\mathbf{a}), \mathrm{Ta}, \mathrm{Nb}, \mathrm{Th}, \mathrm{U}, \mathrm{Cs}, \mathrm{Rb}, \mathrm{Ba}$ and $\mathrm{Sr}$ (b) (all the trace elements concentrations are in ppm). Symbols as in Figure 6. 
As previously indicated, the non-magnetic fraction is responsible for the REE budget of the coastal sands studied. As far as other critical elements are concerned (as they have been determined by European Union), it is clearly indicated that this fraction is as well the most enriched in elements of economic value (Figure 8).

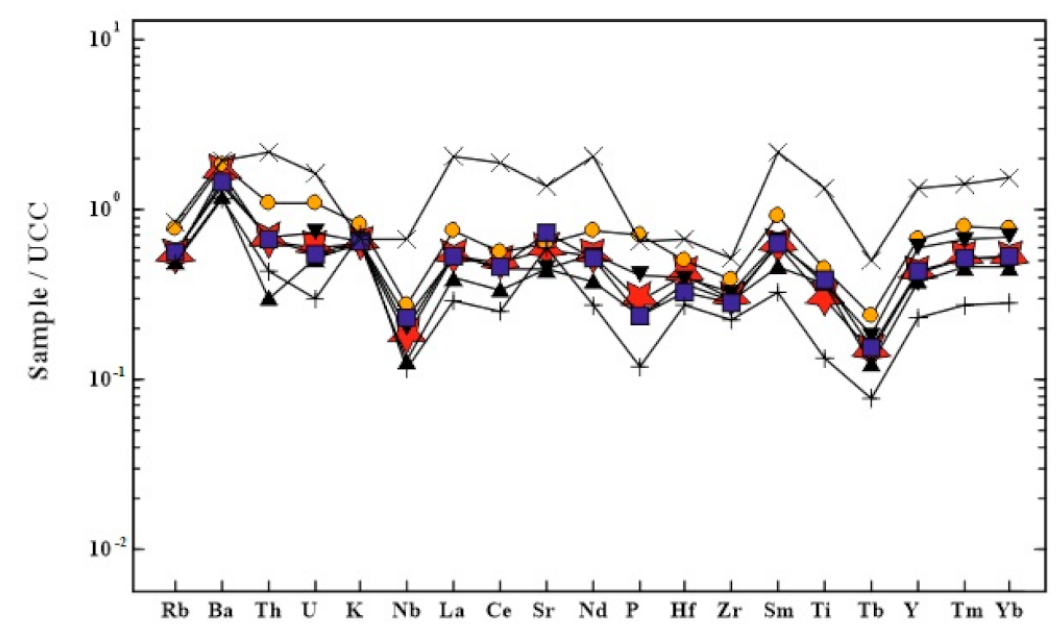

Figure 8. Trace elements of the samples vs UCC concentrations. (UCC normalization after [26]). Symbols as in Figure 5.

Aiming to assess any economic potential of these sands, the respective values have been compared to those obtained by studied by Papadopoulos et al. 2014, 2016 [21,28] for Sithonia and Kavala areas respectively (Figure 9). It is obvious that the studied samples from Aggelochori area lie between the lowest values of these beach placer deposits (Figure 9).



(a)

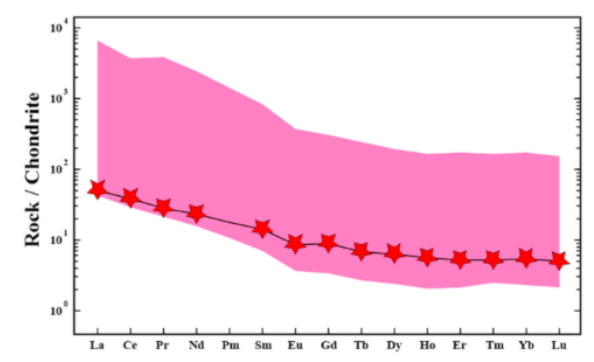

(b)

Figure 9. Comparison of the studied black sands (whole rock) REE pattern with those of (a) Sithonia beach sands (light blue area) and (b) Kavala beach sands (pink area). Symbol (red star) as in Figure 5.

At least, part of the material forming the beach placers from Aggelochori could come from granitic rocks. The most probable granitic sources of this material could be either Fanos granitic rocks and/or Monopigado granitic rocks. Comparing the REE patterns of these rocks with the REE patterns of the studied samples, it seems that there is some similarity with Monopigado granitic rocks (Figure 10).

Moreover, the absence of the characteristic pinkish feldspars of Fanos pluton, implies that the source rock of the studied sediment could possibly be the Monopidado pluton.

REE concentrations are widely used for provenance studies e.g. Tzifas et al. 2017 [29] and references therein. $\mathrm{Ce} / \mathrm{Yb}$ vs $\mathrm{La} / \mathrm{Sm}, \mathrm{Gd} / \mathrm{Yb}$ vs La/Sm and $\mathrm{Eu} / \mathrm{Eu}^{*} / \mathrm{Ce} / \mathrm{Ce}{ }^{*}$ (chondrite normalized values obtained by Nakamura 1974 [30]) are plotted in Figure 11. 


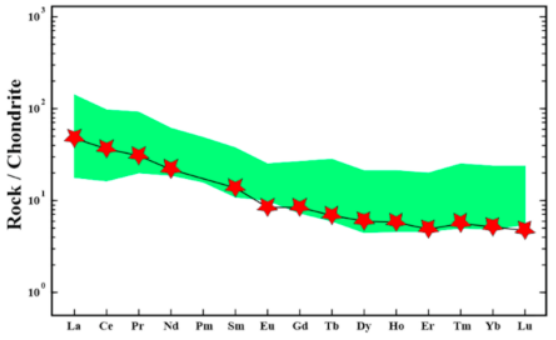

(a)

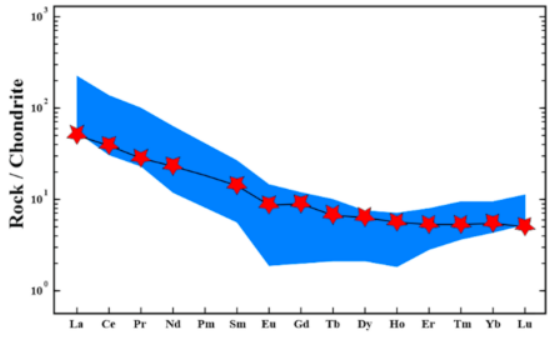

(b)

Figure 10. Comparison of the studied black sands (whole rock) REE pattern with the REE whole rock pattern from (a) Fanos (green area) and (b) Monopigado granitic rocks (blue area). Data from [10,11]. Symbol (red star) as in Figure 5.
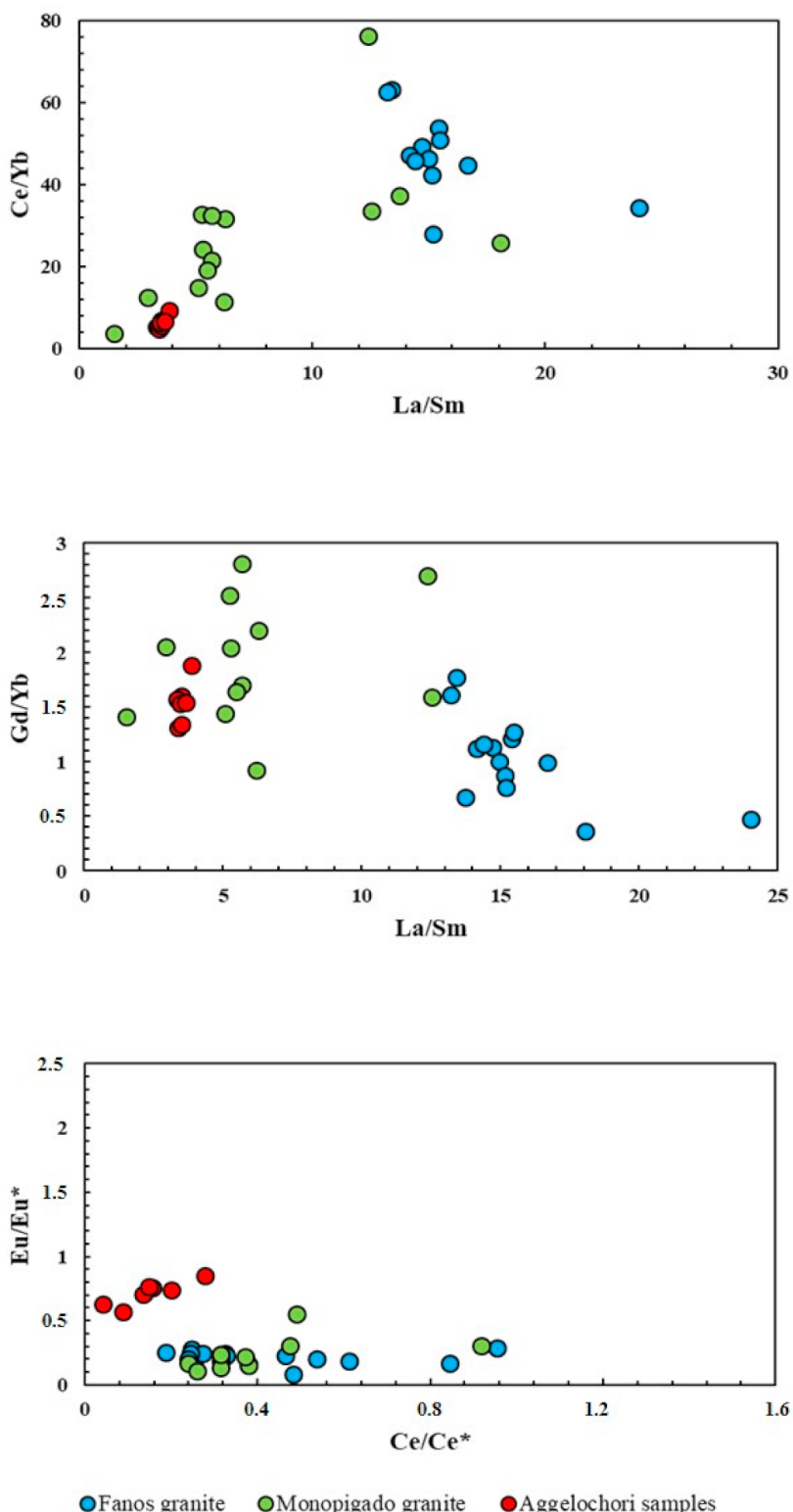

Figure 11. $\mathrm{Ce} / \mathrm{Yb}$ vs $\mathrm{La} / \mathrm{Sm}, \mathrm{Gd} / \mathrm{Yb}$ vs $\mathrm{La} / \mathrm{Sm}$ and $\mathrm{Eu} / \mathrm{Eu}^{*} / \mathrm{Ce} / \mathrm{Ce}$ * for the samples from Aggelochori, Monopigado and Fanos granitic rocks. Symbols for the studied samples as in Figure 5.

It is evident (Figure 11) that there is a resemblance between the Aggelochori samples and the granitic samples from Monopigado pluton, especially as far as Ce/Yb vs La/Sm, $\mathrm{Gd} / \mathrm{Yb}$ vs La/Sm are concerned. 


\section{Conclusions}

According to sediment characterization study the examined sediment samples classified as gravels or gravelly sediments and are typical samples of river fluvial transportation and deposition, showing conditions of relatively high dynamic transport energy for a relatively short distance or excessive flow conditions over an extensive catchment area. The coexistence of the paleo-river channels with cross-stratified sands, along with floodplain deposits on the same stratigraphic horizon, is indicating a substantial flow on a relatively flat area, which agrees with the subtropical fluvio-lacustrine environment mentioned above. The examined sediment samples consist mainly of quartz, feldspars (mainly plagioclase) and phyllosilicate minerals and in minor amounts were found magnetite, pyroxene, amphibole, dolomite and heavy minerals such as zircon, hematite, ilmenite, rutile and titanite. This variety of the mineral constituents, including both ultra-stable detrital non opaque heavy minerals (zircon and titanite), unstable (amphiboles and pyroxenes) and stable to moderate stable opaque heavy minerals hematite and ilmenite, suggests mineralogical immaturity of studied the paleo river deposits and a probable mixed source of the sediments deposited after limited processing of the detrital material in the deposition basin which in turn is the result of the large supply of the river system of the study area in short periods of time, rapid transport and sediment deposition, which is also in good agreement with monsoon subtropical climate prevailing during the period of the deposition.

According to the mineralogical and chemical study, at least part of the source material forming the paleo riverbeds could come from granitic rocks. The most probable granitic sources of this material could be either Fanos granitic rocks and/or Monopigado granitic rocks. Comparing the REE patterns of these rocks with the REE patterns of Aggelochori upper Pliocene fluvial sediments, it seems that there is some similarity with Monopigado granitic rocks, while the absence of the characteristic pinkish feldspars of Fanos pluton and the sedimentological conditions implies that one of the source rock of the studied sediment is possibly some source like Monopigado pluton. This is in contradiction with the observed paleo-river flow direction patterns. The present day Monopigado pluton outcrop is locating downstream of the deposited fluvial sediments as indicating the paleo-flow direction patterns. Either a granite outcrop like Monopigado was existed upstream to sedimentary record covered by more recent sediments, or a more complex flow pattern was existed at the paleo-catchment area of the deposition. A mixed source including both rock-types of Monopigado pluton and metamorphic rocks as well is most probable, as the studied sediments have both magnetite (which is present only in very small quantities, as magnetite can only be found in mafic magmatic enclaves in the rock-types of Monopigado pluton) and ilmenite (which is more often found compared to magnetite, as it is present as accessory mineral in the rock-types of Monopigado pluton) [31]. Moreover, rutile is also indicating the presence of a metamorphic rocks as source rocks. More study is necessary in respect to paleo-hydrographic network in a broader area for a more robust conclusion. The presence of zircons and the fact that zircons of the local plutons have been well studied by Koroneos 2009 [11] leaves a need for further study as they provide a useful tool for provenance studies [32].

About the REE content of the studied samples, the non-magnetic have the highest values. Grain-size does not seem to be the most critical factor affecting the trace element values, but the general image is that the coarser fractions have slightly higher concentrations.

Finally, the REE values of the studied samples, lie between the lowest values of the beach placer deposits in Greece, therefore, their potential for economic exploitation is very limited.

Author Contributions: Conceptualization, A.K. and A.P.; methodology, N.K., K.A., A.P. and A.K.; software S.L. and A.K.-P.; validation, A.K.; N.K. and K.A.; formal analysis, A.P.; investigation, A.P.; resources, A.P.; data curation, A.P.; writing—original draft preparation, A.P.; writing—review and editing, A.P. and S.L.; visualization, S.L. and A.K.-P.; supervision, A.K., N.K. and K.A.; project administration, A.K.; funding acquisition, A.K. All authors have read and agreed to the published version of the manuscript. 
Funding: This research received no external funding.

Data Availability Statement: The authors do not use any data that are nor sited.

Conflicts of Interest: The authors declare no conflict of interest.

\section{References}

1. Papadopoulos, A.; Tzifas, I.T.; Tsikos, H. The Potential for REE and Associated Critical Metals in Coastal Sand (Placer) Deposits of Greece: A Review. Minerals 2019, 9, 469. [CrossRef]

2. Filippidis, A.; Misaelides, P.; Clouvas, A.; Godelitsas, A.; Barbayiannis, N.; Anousis, I. Mineral, chemical and radiological investigation of a black sand at Touzla Cape, near Thessaloniki, Greece. Environ. Geochem. Health 1997, 19, 83-88. [CrossRef]

3. Kydonakis, K.; Brun, J.P.; Sokoutis, D.; Gueydan, F. Kinematics of Cretaceous subduction and exhumation in the western Rhodope (Chalkidiki block). Tectonophysics 2015, 665, 218-235. [CrossRef]

4. Kockel, F.; Mollat, H.; Walther, H.W. Geologie des Serbo-Mazedonischen Massivs und seines mesozoischen Rahmens (Nord griechenland). Geol. Jahrb. 1971, 89, 529-551.

5. Kockel, F.; Mollat, H.; Walther, H. Erlauterungen zur Geologischen Karte der Chalkidiki und angrenzender Gebiete 1:100000 (NordGriechenland); Bundesanstalt für Geowissenschaften und Rohstoffe: Hannover, Germany, 1977; p. 119.

6. Monod, O. Etude Géologique de Massif de Chortiatis (MacédoineGreque). Ph.D. Thesis, Université de Paris, Paris, France, 1964.

7. Mussallam, K.; Jung, D. Petrology and geotectonic significance of salic rocks preceding ophiolites in the Eastern Vardar Zone, Greece. Tschermaks Mineral. Und Petrogr. Mitt. 1986, 35, 217-242. [CrossRef]

8. Ivanova, D.; Bonev, N.; Chatalov, A. Biostratigraphy and tectonic significance of lowermost Cretaceous carbonate rocks of the Circum-Rhodope Belt (Chalkidhiki Peninsula and Thrace region, NE Greece). Cretac. Res. 2015, 52, 25-63. [CrossRef]

9. Jung, D.; Mussallam, K. The Sithonia ophiolite: A fossil oceanic crust. Ofioliti 1985, 10, 329-342.

10. Christofides, G.; Soldatos, T.; Koroneos, A. Geochemistry and Evolution of the Fanos Granite, N. Greece. Mineral. Petrol. 1990, 43, 49-63. [CrossRef]

11. Koroneos, A. Petrogenesis of the Upper Jurassic Monopigadon pluton related to the Vardar/Axios ophiolites (Macedonia, northern Greece) and its geotectonic significance. Chem. Der Erde 2009, 70, 221-241. [CrossRef]

12. Syrides, G.E. Lithostratigraphic, Biostratigraphic and Palaeogeographic Study of the Neogene-Quaternary Sedimentary Deposits of Chalkidiki Peninsula, Macedonia, Greece. Ph.D. Thesis, University of Thessaloniki, Thessaloniki, Greece, 1990.

13. Koufos, G.; Syrides, G.; Koliadimou, K. A Pliocene primate from Macedonia (Greece). J. Hum. Evol. 1991, 21, 283-294. [CrossRef]

14. Koufos, G.; Koliadimou, K. Two lagomorphs, from the Pliocene of Macedonia, Greece. Bull. Geol. Soc. Greece 1993, $28,117-129$.

15. Filippidis, A.; Kantiranis, N. Experimental neutralization of lake and stream waters from N. Greece using domestic HEU-type rich natural zeolitic material. Desalination 2007, 213, 47-55. [CrossRef]

16. Folk, R.L.; Andrews, P.B.; Lewis, D.W. Detrital sedimentary rock classification and nomenclature for use in N. Zealand. New Zealand J. Geol. Geophys. 1970, 13, 937-968. [CrossRef]

17. Schlee, J. Atlantic continental shelf and slope of the United States-Sediment texture of the northeastern part. U.S. Geol. Surv. Prof. Pap. 1973. [CrossRef]

18. Venetikidis, A. Sedimentological and Petrological Study of the Quaternary Clastic Sediments of the Mygdonia Basin at the Platanorema Locality, Lagkadikia, N. Greece. Master's Thesis, Aristotle University of Thessaloniki, Thessaloniki, Greece, 2012.

19. Livas, A. Study of the Quaternary clastic materials of the Internal Thermaikos Gulf, Thessaloniki (Greece). Master's Thesis, School of Geology, Aristotle University of Thessaloniki, Thessaloniki, Greece, 2017.

20. Velitzelos, D.; Bouchal, J.M.; Denk, T. Review of the Cenozoic floras and vegetation of Greece. Rev. Palaeobot. Palynol. 2014, 204, 56-117. [CrossRef]

21. Papadopoulos, A.; Christofides, G.; Pe-Piper, G.; Koroneos, A.; Papadopoulou, L. Geochemistry of beach sands from Sithonia Peninsula (Chalkidiki, Northern Greece). Mineral. Petrol. 2014, 109, 53-66. [CrossRef]

22. Blatt, H.; Middleton, G.; Murray, R. Origin of Sedimentary Rocks; Prentice-Hall: Hoboken, NJ, USA, $1972 ;$ p. 634.

23. Tucker, M. Sedimentary Petrology, 3rd ed.; Wiley: Hoboken, NJ, USA, 2001; p. 272.

24. Papadopoulos, A. Geochemistry and REE content of beach sands along the Atticocycladic coastal zone, Greece. Geosci. J. 2018, 22, 955-973. [CrossRef]

25. Tsirambides, A.; Kantiranis, N. Composition and origin of the recent fluvial deposits of Evros (Thrace). Bull. Geol. Soc. Greece 1998, 32, 329-337.

26. Taylor, S.R.; McLennan, S.M. The Continental Crust: Its Composition and Evolution; An Examination of the Geochemical Record Preserved in Sedimentary Rocks; Blackwell: Oxford, UK, 1985; p. 312.

27. Boynton, W.V. Geochemistry of rare earth elements: Meteorites studies. In Rare Earth Element Geochemistry; Henderson, P., Ed.; Elsevier: New York, NY, USA, 1984; pp. 63-114.

28. Papadopoulos, A.; Koroneos, A.; Christofides, G.; Papadopoulou, L. Geochemistry of beach sands from Kavala, Northern Greece. Ital. J. Geosci. 2016, 135, 526-539. [CrossRef]

29. Tzifas, I.T.; Misaelides, P.; Godelitsas, A.; Gamaletsos, P.N.; Nomikou, P.; Karydas, A.G.; Kantarelou, V.; Papadopoulos, A. Geochemistry of coastal sands of Eastern Mediterranean: The case of Nisyros volcanic materials. Geochemistry 2017, 77, 487-501. [CrossRef] 
30. Nakamura, N. Determination of $\mathrm{REE}, \mathrm{Ba}, \mathrm{Fe}, \mathrm{Mg}, \mathrm{Na}$, and $\mathrm{K}$ in carbonaceous and ordinary chondrites. Geochim. Cosmochim. Acta 1974, 38, 757-775. [CrossRef]

31. Morton, A.C.; Hallsworth, C.R. Processes controlling thecomposition of heavy mineral assemblages in sandstones. Sediment. Geol. 1999, 124, 3-29. [CrossRef]

32. Dill, H.G.; Weber, B.; Klosa, D. Morphology and mineral chemistry of monazite-zircon-bearing stream sediments of continental placer deposits (SE Germany): Ore guide and provenance marker. J. Geochem. Explor. 2012, 112, 322-346. [CrossRef] 